\title{
Five new species of Neusterensifer from western New Guinea (Heteroptera: Veliidae) with biogeographic notes
}

\author{
Dan A. Polhemus \& John T. Polhemus
}

\begin{abstract}
Five new species of Neusterensifer are described from western New Guinea and adjacent Yapen Island. The new taxa are as follows: Neusterensifer dabrana sp.n. and Neusterensifer terrestris sp.n. from the Mamberamo River basin; Neusterensifer timikana sp.n. from the Ajkwa River basin; Neusterensifer wondiwoi sp.n. from the Wandammen Peninsula; and Neusterensifer yobi sp.n. from Yapen Island. New distribution records are also provided for Neusterensifer gladius Polhemus \& Polhemus from the Wandammen and Mangguar peninsulas of western New Guinea. Illustrations of key characters, color dorsal habitus photos, and distribution maps are provided for all new species treated, accompanied by a comprehensive checklist of Neusterensifer species and their geographic distributions, with species assigned to their freshwater areas of endemism within the island. The refined knowledge of species distributions based on these new collections indicates that the Wandammen Peninsula should likely be considered a discrete area of freshwater endemism within New Guinea. Dr. Dan A. Polhemus, Dept. of Natural Sciences, Bishop Museum, 1525 Bernice St., Honolulu, HI 96817 USA. bugman@bishopmuseum.org

Dr. John T. Polhemus, Colorado Entomological Institute, 3115 S. York St., Englewood, CO 80110 USA
\end{abstract}

\section{Introduction}

This paper represents another contribution to our continuing taxonomic study of the rich and highly endemic assemblage of genera and species in the Heteroptera subfamily Microveliinae occurring in the Melanesian region, much of which is still undocumented. The most speciose genus within this regional assemblage is Neusterensifer Polhemus \& Polhemus, 1994, which is endemic to New Guinea and nearby islands. In this paper, five new species in this genus are described, bringing the total number of recognized Neusterensifer species to 35 (see Appendix 1). The current work builds on previous contributions by J. Polhemus \& D. Polhemus (1994), D. Polhemus \& J. Polhemus (2000a, 2000b, 2004), and Chen et al. (2008), and focuses on the Neusterensifer biota of western of New Guinea, including both the northern and southern flanks of the central mountain ranges, and certain offshore islands.

The included checklist of species also assigns taxa to 

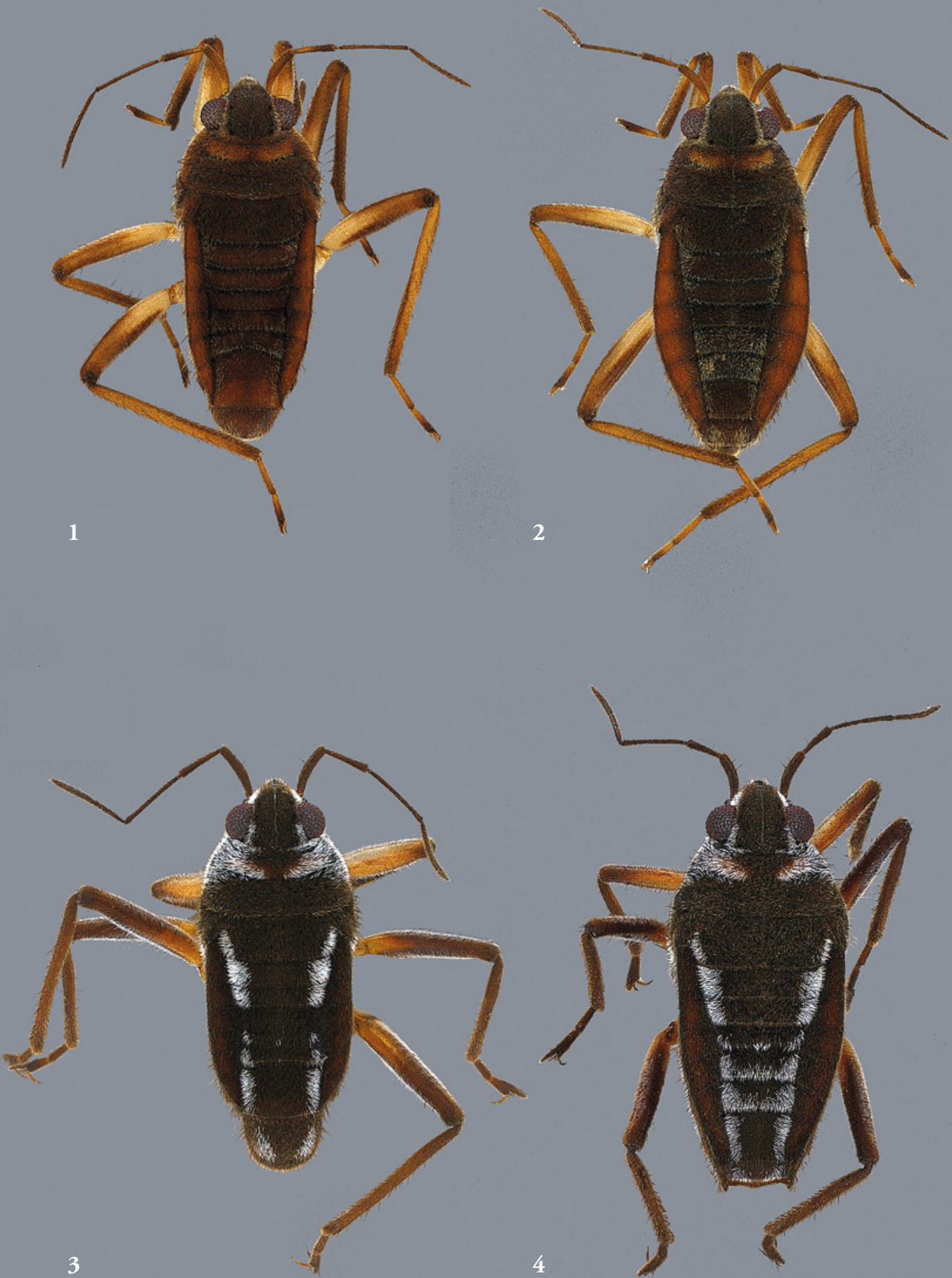

Figs 1-4. Neusterensifer species, dorsal habitus photos (all specimens from New Guinea, Tiri River, CL 7140). 1. N. terrestris, micropterous male; 2. N. terrestris, micropterous female; 3. N. dabrana, micropterous male; 4. N. dabrana, micropterous female. 


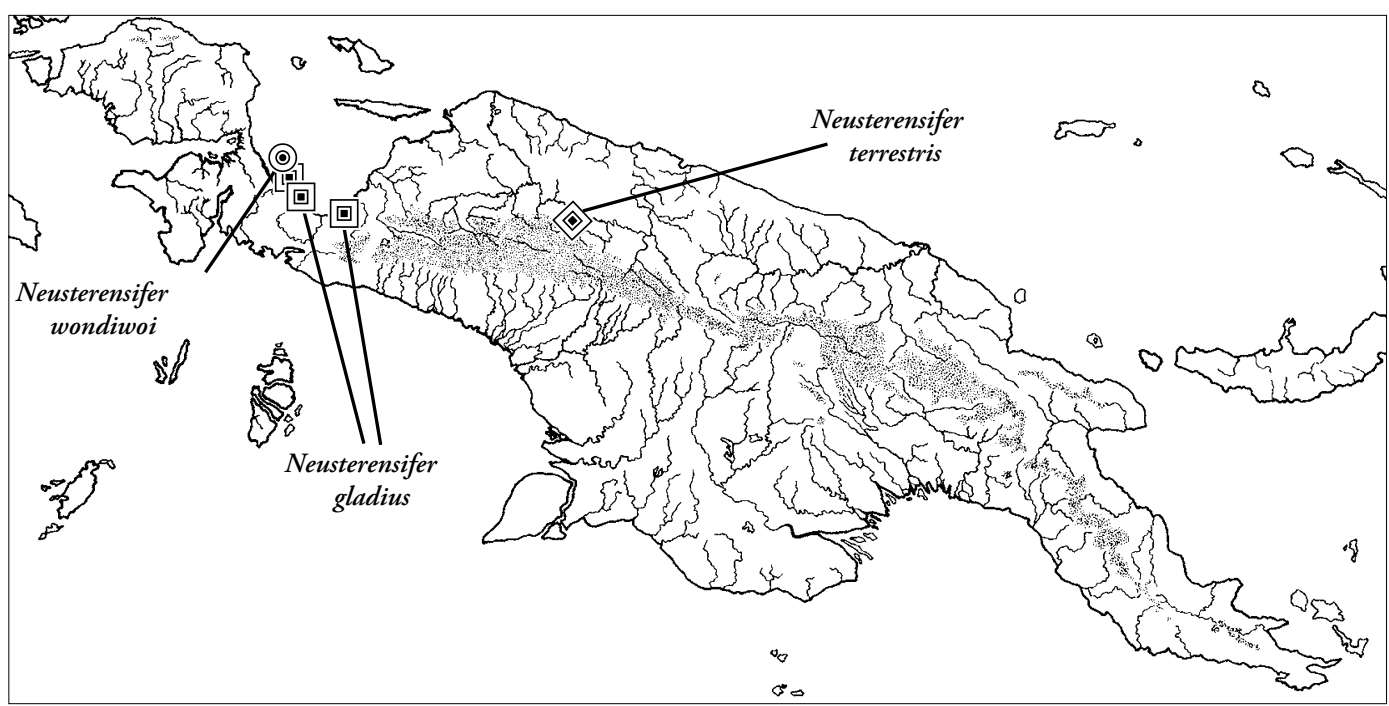

Fig. 5. Distribution of Neusterensifer species on New Guinea. Diamond $=N$. terrestris; squares $=N$. gladius, circle $=N$. wondiwo $i$

areas of freshwater endemism for the New Guinea region as defined by D. Polhemus \& Allen (2007). The species distributions of both new and previously described species of Neusterensifer conform well to this scheme, and are thus consistent with previous distributional results reported for other groups of Heteroptera such as Ptilomera (D. Polhemus \& J. Polhemus 2001), and for the aquatic Coleoptera families Gyrinidae (D. Polhemus 2011) and Hydraenidae (Perkins 2011).

\section{Material and methods}

The specimens reported on below were collected by hand netting. The specimens were preserved on-site in $75 \%$ ethanol, and subsequently transported to the Smithsonian Institution, Washington, DC (USNM) or the Bishop Museum (BPBM), Honolulu, Hawaii for sorting and identification. Synoptic series were then dry mounted on points, with the measurements and descriptions presented below taken from such dry mounted specimens

All measurements are given in millimeters. GPS readings were taken at collecting sites in WGS 84 datum, using a Garmin hand-held satellite global positioning system. Water temperatures were taken at the water surface using a hand-held thermometer. The CL numbers in the material examined sections refer to a series of collection locality numbers used by the authors to catalog sampling sites and associated metadata in the Melanesian region as a whole.

Color illustrations were prepared at Bishop Museum using an AutoMontage system, with the plates subsequently edited in PhotoShop CS 9.0.2 to remove artifacts such as small dust particles.

\section{Taxonomy}

\section{Neusterensifer Polhemus \& Polhemus}

Neusterinsifer J. Polhemus \& D. Polhemus, 1994: 67 (type species Neusterinsifer compacta Polhemus \& Polhemus, 1994, by original designation).

Neusterensifer D. Polhemus \& J. Polhemus 2000a: 113 (justified emendation).

\section{Discussion}

The diagnostic structural characters of this genus were provided by Polhemus \& Polhemus (1994) and are not repeated here. However, in reading the descriptions below it is very important to bear in mind that in Neusterensifer the more commonly encountered "wingless" forms are actually micropterous, so that the first abdominal tergite is covered by the metanotum. The first visible abdominal tergite dorsally in both males and females is therefore tergite II. In males, the best way to ascertain tergite numbering is count backward from the cylindrical first genital segment, which represents tergite VIII. Similarly, in females one may count backward from the proctiger, which represents tergite IX.

Ventrally, abdominal ventrite $\mathrm{I}$ is barely visible as a vertical plate lying between the metasternum and 
well-developed abdominal ventrite II. By working backward from this it is possible to see that the final connexival segment is formed by the laterotergites of abdominal segment VII, thus as in the abdominal tergites, the first visible connexivum anteriorly is segment II.

\section{Neusterensifer terrestris sp. $\mathbf{n}$.}

Figs 1, 2, 5, 17, 23

Type material. Holotype, micropterous male: Indonesia, Papua Prov. [= former Irian Jaya Prov.], damp and muddy depressions in forest adjacent to Tiri River (trib. to Doorman River), $4.5 \mathrm{~km} \mathrm{SW}$ of Dabra, 80 m [260 ft.], water temp. $25^{\circ} \mathrm{C}$., 913 September 2000, 317’30” S, $138^{\circ} 34^{\prime} 53^{\prime \prime}$ E, CL 7140, D. A. Polhemus (USNM).

Paratypes: Indonesia, Papua Prov. [= former Irian Jaya Prov.]: 35 micropterous males, 32 micropterous females, same data as holotype, D. A. Polhemus (USNM, BPBM).

\section{Description}

Size. Micropterous male, length $2.28-2.40 \mathrm{~mm}(\overline{\mathrm{x}}=$ $2.35, \mathrm{n}=6)$; width $0.85-1.00 \mathrm{~mm}(\overline{\mathrm{x}}=0.92, \mathrm{n}=$ 6). Micropterous female, length $2.35-2.50 \mathrm{~mm}(\overline{\mathrm{x}}=$ $2.42, \mathrm{n}=5)$; width $1.00-1.05 \mathrm{~mm},(\overline{\mathrm{x}}=1.01, \mathrm{n}=6)$. Color. Micropterous male (Fig. 1): Ground color orange brown, marked with yellowish brown on anterior pronotum and legs, pronotum and mesonotum medium brown; sparse patches of short, shining, silvery pubescence present narrowly along lateral and posterior margins of metanotum and abdominal tergites II and III, narrowly along posterior margins of abdominal tergites IV-VI, along anterior margin of pronotum, and on sides of thorax and abdomen. Head medium brown; antennae uniformly medium brown; rostrum pale whitish-yellow, fuscous medially, piceous distally. Pronotum and metanotum medium brown; anterior pronotum bearing a pair $(1+1)$ of elongate transverse yellowish brown spots to either side of narrow midline behind anterior margin. Abdomen including connexiva orangebrown dorsally, laterotergites broadly dark brown below connexiva. Legs generally medium brown, with coxae, trochanters, femora and ventral halves of tibiae pale whitish-yellow. Venter dark brown, acetabulae orange-brown.

Structural characters. Micropterous male: head of moderate length, declivant anteriorly, with weak impressed median line; length 0.40 , width 0.60 ; width of eye/interocular space, $0.15 / 0.30$. Pronotum long, covering mesonotum, length/width, $0.40 / 0.92$. Metanotum length 0.30 . Abdominal tergites dull, without shining areas; lengths of tergites II-VII, respectively: $0.20: 0.15: 0.10: 0.15$ : $0.15: 0.40$.

Entire dorsum and laterotergites covered with fine appressed golden pubescence, intermixed with numerous long, erect golden-brown setae. Antennae thickly clothed with short gold setae, scattered long erect brown setae present along anterior margins of antennal segments I-III, lengths of these latter setae exceeding width of segments on which they occur. Pronotum with humeri depressed; anterior section bearing a single transverse row of coarse punctuations behind head; posterior section bearing several transverse rows of coarse punctuations; similar punctuations also present on metanotum. Legs thickly clothed with short gold setae, intermixed with longer golden-brown setae along anterior margins of all tibiae; posterior margins of all femora bearing thick fringe of very short, densely packed pale setae; posterior margin of middle femur bearing 12-14 evenly spaced long, slender, erect brown setae; posterior margin of middle tibia bearing 6 very long, erect, slender brown setae evenly spaced on distal half, longest and most basal of these setae with length over $2 \times$ width of tibia; ventral margin of fore femur with a slight concavity on distal one-third.

Prosternum broadly sulcate along longitudinal midline; mesosternum slightly bitumescent, with broad, shallow sulcus posteromedially; metasternum tumid. Abdominal venter dull, lacking evident setae; abdominal ventrite I very short, barely exposed; abdominal ventrites II-IV broadly arching, unmodified; abdominal ventrite $\mathrm{V}$ bearing a shallow, narrow sulcus along longitudinal midline; abdominal ventrite VI produced posteromedially into a semicircular process extending over base of ventrite VII, posterior apex of this process bearing a small tuft of dense black setae, this tuft in the shape of a posteriorly directed triangle; abdominal ventrite VII broadly excavate and concave medially, anteromedial section angling strongly upward when viewed laterally, posteromedial section forming a broad, horizontally oriented lamella adjoining base of genital capsule. Proctiger produced anteriorly into a moderately long, curving, blade-like process with an acute apex, and a small secondary process arising from base of anterior margin (Fig. 17). Parameres vestigial or absent.

Antennal formula I : II : III : IV; $0.35: 0.30: 0.50$ : 0.58 .

Proportions of legs as follows: Femur, tibia, tarsal 1, tarsal 2 of fore leg, $0.65: 0.61: 0.31: 0.0$; of middle leg, $0.90: 0.80: 0.20: 0.30$; of hind leg, $0.95: 1.30$ : $0.25: 0.25$.

Micropterous female (Fig. 2). Similar to micropterous male in general structure and color, with following 
exceptions: general coloration of dorsal head, thorax and abdomen dark brown, with dorsal connexiva orange-brown; metanotum and abdominal tergites II-VII with small patches of silvery setae laterally and along posterior margins, abdominal tergite VIII with a pair $(1+1)$ of silvery setal patches centrally to either side of midline; connexiva with lateral margins broadly curving outward, margins of even thickness throughout, posterolateral angles not produced, widely separated, leaving all abdominal tergites completely exposed and visible from above; abdominal tergite VIII angled downward at approximately $45^{\circ}$ when viewed laterally (Fig. 23); proctiger angled downward in nearly vertical orientation and cupped within lateral and posteroventral margins of abdominal ventrite VII, with posterior apex barely projecting beyond posterior margin of ventrite VII; abdominal venter unmodified, with all ventrites broadly and smoothly curving, lacking sulci or processes; leg segments simple and unmodified, fore femur lacking distal concavity ventrally.

Macropterous form. Unknown.

\section{Etymology}

The species name is derived from the Latin "terrestris", of the earth, and refers to the habitat of this species, which occupies damp mud pans on the floor of seasonally flooded tropical rain forest.

\section{Distribution}

Western New Guinea (Fig. 5).

\section{Comparative notes}

Neusterensifer terrestris may be recognized by its orange-brown ground coloration and very limited extent of silvery setal patches on the pronotum and abdominal tergites in both sexes (Figs 1,2), the strongly hooked process on the male proctiger with a basal secondary tubercle (Fig. 17), the presence of a single setiferous tubercle on male abdominal ventrite VI projecting posteriorly over a concavity on the basally excavate portion of ventrite VII, and the unmodified form of the terminal female abdominal segments when viewed laterally (Fig. 23). This species also has tarsal segment I of the hind leg elongated, such that its length is equivalent to that of hind tarsal segment II, rather than being shorter than hind tarsal segment II as seen in all other species of Neusterensifer known to date.

This is one of the more morphologically distinctive species in the genus, with a body form that is somewhat more elongate and less robust than most other Neusterensifer, coupled with the hind tarsal modifications noted above. These character states are likely to be related to its damp terrestrial rather than aquatic habitat preferences. The morphological ground plan of $N$. terrestris, however, conforms to that of Neusterensifer as a whole, and the modifications of the male proctiger are consistent with placement in this genus (compare Figs 15-19).

\section{Ecological notes}

The type series was taken from a set of damp, muddy, shaded depressions on the floor of a tall, seasonally flooded forest adjacent to the Sungai Tiri, a low gradient tributary of the Doorman River emerging from the northern foothills of the central New Guinea mountains. The insects ran over the muddy surface in company with Mesovelia subvittata Horváth, 1915 and an undescribed Ochterus species, and were found only in this habitat, being absent along the margins of the river itself. This, in combination with the elongate tarsi, suggests that this species is specifically adapted to inhabit these seasonally flooded depressions. Because such areas are not often sampled by aquatic entomologists, this further suggests that this species or others similar to it will be found in floodplain habitats throughout New Guinea.

Based on known collections, this species occupies the Mamberamo Foreland area of freshwater endemism (Area 17) as defined by Polhemus \& Allen (2007).

\section{Neusterensifer dabrana sp. $\mathbf{n}$.}

Figs 3, 4, 9, 16, 24

Type material. Holotype, micropterous male: Indonesia, Papua Prov. [= former Irian Jaya Prov.], pools in sandy overflow channel branching from Tiri River (trib. to Doorman River), $4.5 \mathrm{~km} \mathrm{SW}$ of Dabra, $80 \mathrm{~m}$. [260 ft.], $3^{\circ} 17^{\prime} 30^{\prime \prime} \mathrm{S}, 138^{\circ} 34^{\prime} 53^{\prime \prime} \mathrm{E}$, water temp. $25^{\circ}$ C., 9-13 September 2000, CL 7141, D. A. Polhemus (USNM).

Paratypes: Indonesia, Papua Prov. [= former Irian Jaya Prov.]: 7 micropterous males, 7 micropterous females, same data as holotype, D. A. Polhemus (USNM, BPBM);1 micropterous male, 1 micropterous female, upper Furu River (trib. to Idenburg River), $3 \mathrm{~km}$. SE of Dabra, $90 \mathrm{~m}$. [300 ft.], water temp. $25.5^{\circ} \mathrm{C}$., 4-7 September 2000, $3^{\circ} 17^{\prime} 04$ " S, 138³8'10” E, CL 7135, D. A. Polhemus (USNM); 2 micropterous males, 1 micropterous female, Furu River (trib. to Idenburg River) and sand bottomed tributary, $3 \mathrm{~km} \mathrm{SE}$ of Dabra, $80 \mathrm{~m}$. [260 ft.], $3^{\circ} 16^{\prime} 45^{\prime \prime} \mathrm{S}, 138^{\circ} 38^{\prime} 24^{\prime \prime} \mathrm{E}$, water temp. $25.5^{\circ} \mathrm{C}$., 7 September 2000, 08:30-09:30 hrs., CL 7138, D. A. Polhemus (USNM).

\section{Description}

Size. Micropterous male, length $2.25-2.50 \mathrm{~mm}(\overline{\mathrm{x}}=$ $2.35, \mathrm{n}=5)$; width $0.90-1.00 \mathrm{~mm}(\overline{\mathrm{x}}=0.96, \mathrm{n}=5)$. 


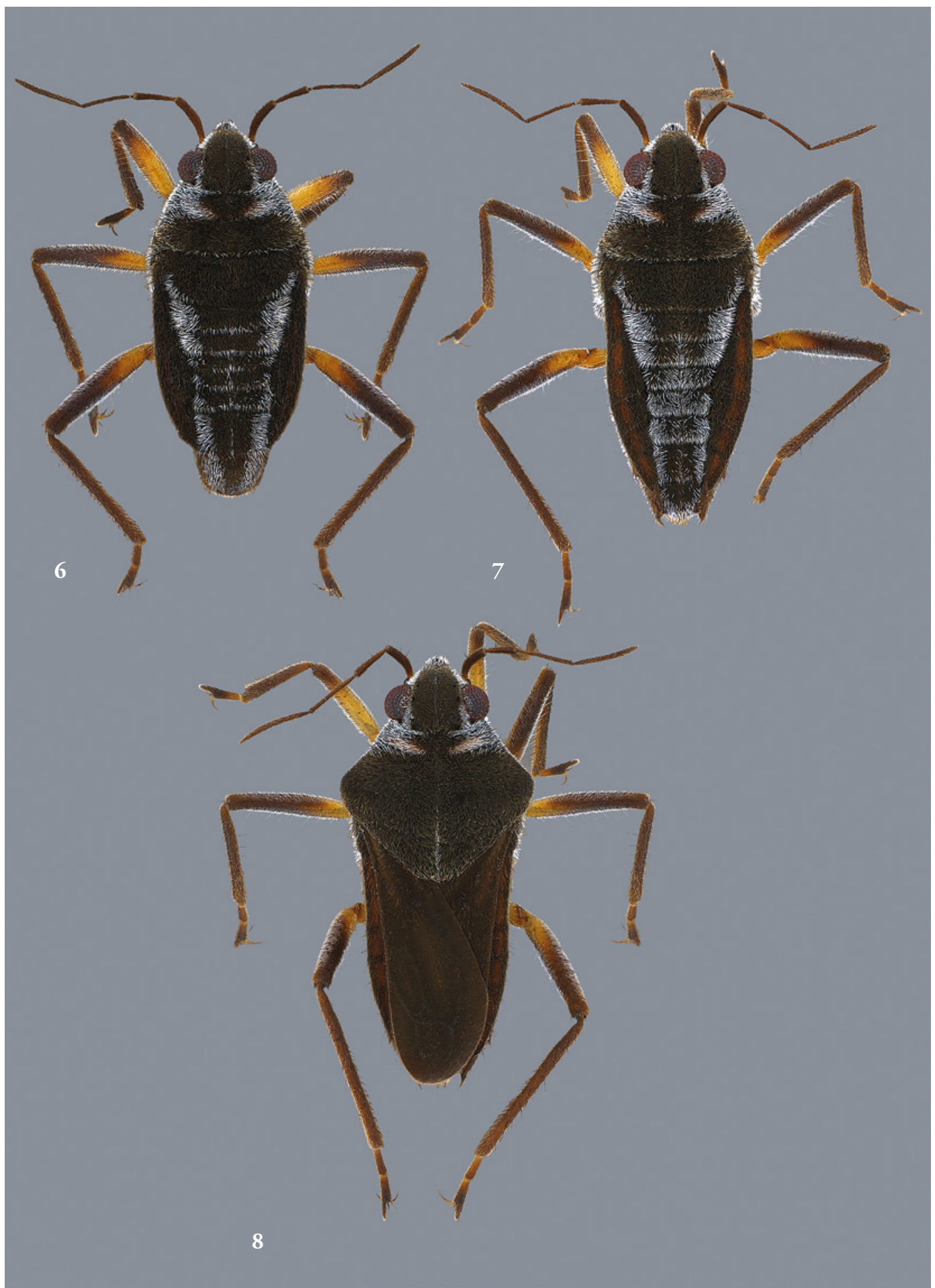

Figs 6-8. Neusterensifer timikana, dorsal habitus photos (all specimens from New Guinea, Ajkwa River, CL 7052). 1. Micropterous male; 2. Micropterous female; 3. Macopterous female 


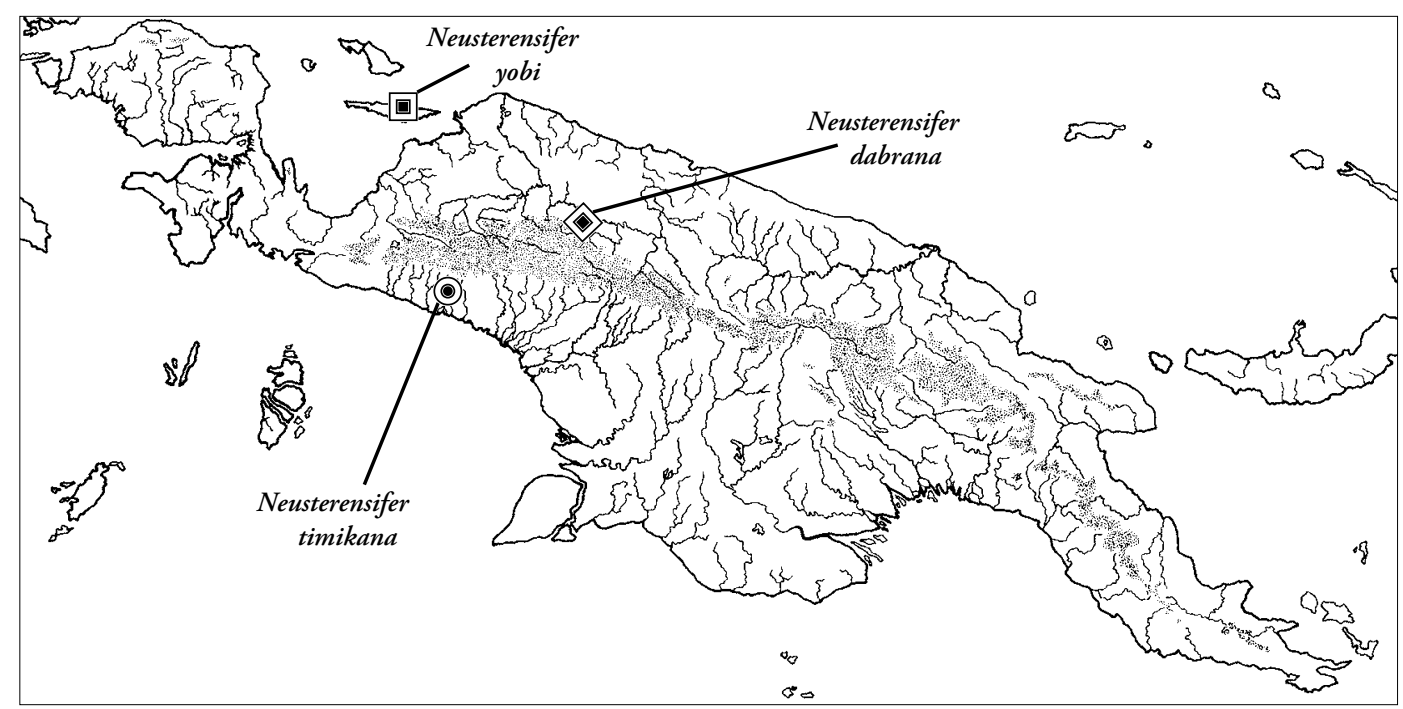

Fig. 9. Distribution of Neusterensifer species on New Guinea. Diamond $=N$. dabrana; square $=N$. yobi, circle $=$ N. timikana

Micropterous female, length $2.40-2.50 \mathrm{~mm}(\overline{\mathrm{x}}=$ $2.47, \mathrm{n}=5)$; width $1.05-1.15 \mathrm{~mm},(\overline{\mathrm{x}}=1.07, \mathrm{n}=5)$. Color. Micropterous male (Fig. 3): Ground color dark brown, marked with orange brown on anterior pronotum; patches of short, shining, silvery pubescence present laterally on frons, vertex, pronotum, metanotum, and abdominal tergites II, III, V, VI and VII; in broad band across anterior pronotum; and on sides of thorax and abdomen. Head dark brown; eyes dark red; antennae uniformly medium brown; rostrum dark yellow, dark red medially, piceous distally. Pronotum dark brown, bearing a pair $(1+1)$ of elongate transverse orange brown spots to either side of midline behind anterior margin. Metanotum and abdominal tergites dark brown, connexiva medium brown on outer halves and ventrally. Legs with coxae, trochanters, and majority of femora dark yellow; distal tips of femora, plus all tibiae and tarsi yellowish brown. Laterotergites below connexiva and all ventral surfaces dull black, except propleural region brown.

Structural characters. Micropterous male: head of moderate length, declivant anteriorly, with weak impressed median line; length 0.50 , width 0.62 ; width of eye/interocular space, 0.15/0.32. Pronotum long, covering mesonotum, length/width, $0.45 / 0.90$. Metanotum length 0.45 . Abdominal tergites dull, without shining areas; lengths of tergites II-VII, respectively: $0.20: 0.15: 0.10: 0.08: 0.08$ $: 0.40$.

Entire dorsum and laterotergites covered with fine appressed golden pubescence, intermixed with scattered long, erect golden-brown setae; legs and antennae thickly clothed with short pale setae, scattered long erect black setae present along anterior margins of antennal segments I and II, anterior margins of all tibiae; fore femur ventral margin straight, not modified, bearing numerous short, erect pale setae along entire length, intermixed with evenly spaced comb of 6-8 long, erect, pilose pale setae; fore tibiae with inner margin straight, distal grasping comb extending for $0.4 \times$ the length of the segment; middle tibia bearing a row of evenly spaced, long pilose pale setae of progressively decreasing length, longest and most basal of these setae with length approximately exceeding $2 \times$ width of tibia; hind femur with numerous short, erect pale setae along posterior margin, lacking tumescences or specialized setal tufts.

Pro- and mesosternum broadly sulcate along longitudinal midlines; metasternum slightly tumescent. Abdominal venter set with very short appressed pale setae, and scattered longer pale setae; abdominal ventrites I-IV unmodified; ventrites V and VI shallowly sulcate centrally along longitudinal midline; ventrite VII with a roughly triangular depression posteromedially, the apex of this triangle directed anterad, this depression flanked by a pair $(1+1)$ of raised carinae angling backward and outward. Proctiger produced anteriorly into a very long, multisinuate process tapering to a slightly rounded apex (Fig. 16); anterior margin of abdominal ventrite VIII with prominent conical tubercle arising immediately posterior to 
elongate process originating on proctiger. Parameres vestigial or absent.

Antennal formula I : II : III : IV; $0.35: 0.30: 0.48$ : 0.50 .

Proportions of legs as follows: Femur, tibia, tarsal 1, tarsal 2 of fore leg, $0.70: 0.50: 0.25: 0.0$; of middle leg, $1.00: 0.90: 0.20: 0.30$; of hind leg, $0.90: 1.10$ : $0.18: 0.22$.

Micropterous female (Fig. 4). Similar to micropterous male in general structure and color, with following exceptions: all abdominal tergites with small patches of silvery setae laterally, tergites IV-VI bearing narrow bands of silvery setae across their posterior margins, abdominal tergite VIII with anterior half lying $45^{\circ}$ from vertical when viewed laterally, posterior half bent more sharply downward into nearly vertical orientation; connexiva broadly separated, bowing slightly outward, margins gradually convergent posteriorly, posterolateral apices of segment VII produced into small, angulate, posterior projections when viewed dorsally, rounded when seen in lateral view (Fig. 24); connexival margins of even width throughout, lacking specialized setal tufts; abdominal venter unmodified, set with numerous very short pale setae; legs unmodified.

Macropterous form. Unknown.

\section{Etymology}

The name "dabrana" refers to the type locality, near the village of Dabra in western central New Guinea.

\section{Distribution}

Western New Guinea (Fig. 9).

\section{Comparative notes}

Neusterensifer dabrana is a dark colored species (Figs 3, 4) that can be easily recognized by the very long, multisinuate process on the male proctiger (Fig. 16), the presence of a prominent conical tubercle arising from abdominal segment VIII immediately posterior to the proctiger, the form of the ventral male abdomen which lacks setiferous tubercles but does possess a pair of raised carinae angling backward and posteriorly outward on the posterior half of ventrite VI, and the rounded form of the female connexival apices when viewed laterally (Fig. 24).

\section{Ecological notes}

This species was common in small water pockets amid cobbles along the margins of first and second order streams shaded by primary rain forest in the Furu River catchment near Dabra, and also occurred on standing or slowly flowing pools in sandy, shaded overflow channels amid seasonally flooded primary rain forest in the Doorman River catchment to the west. All of these streams are tributaries to the Idenberg branch of the Mamberamo River system in western central New Guinea.

Based on known collections, this species occupies the Mamberamo Foreland area of freshwater endemism (Area 17) as defined by Polhemus \& Allen (2007).

\section{Neusterensifer timikana sp. $\mathbf{n}$.}

Figs 6-9, 18, 21

Type material. Holotype, micropterous male: Indonesia, Papua Prov. [= former Irian Jaya Prov.], overflow channel adjacent to Ajkwa River above gravel mining area, N. of Kuala Kencana, $170 \mathrm{~m}$ [550 ft.], 424'12"S, $136^{\circ} 53^{\prime} 54^{\prime \prime} \mathrm{E}$, water temp. $26^{\circ} \mathrm{C}$., 20 January 1997, 15:00-17:00 hrs., CL 7052, D.A. Polhemus (USNM).

Paratypes: Indonesia, Papua Prov. [= former Irian Jaya Prov.]: 1 macropterous female, 32 micropterous males, 7 micropterous females, same data as holotype, D. A. Polhemus (USNM, BPBM).

\section{Description}

Size. Micropterous male, length $2.20-2.37 \mathrm{~mm}$ $(\overline{\mathrm{x}}=2.30, \mathrm{n}=7)$; width $0.90-1.05 \mathrm{~mm}(\overline{\mathrm{x}}=0.98$, $\mathrm{n}=7)$. Micropterous female, length $2.40-2.50 \mathrm{~mm}$ $(\overline{\mathrm{x}}=2.48, \mathrm{n}=5)$; width $1.00-1.10 \mathrm{~mm},(\overline{\mathrm{x}}=1.06, \mathrm{n}$ = 5). Macropterous female, length $2.70 \mathrm{~mm}(\mathrm{n}=1)$; width $1.20 \mathrm{~mm},(\mathrm{n}=1)$.

Color. Micropterous male (Fig. 6): Ground color dark grey, marked with orange brown on anterior pronotum; patches of short, shining, silvery pubescence present laterally on frons, vertex, pronotum, metanotum, and abdominal tergites II, III, V-VIII, in narrow transverse bands along posterior margins of pronotum and abdominal tergites II, V and VI; in broad band across anterior pronotum; and on sides of thorax and abdomen. Head dark grey; eyes dark red; antennae with segment I and basal half of segment II yellowish brown, distal half of segment II and segments III and IV darker brown; rostrum dark yellow, dark brown medially, piceous distally. Pronotum dark grey, bearing a pair $(1+1)$ of elongate transverse orange brown spots to either side of midline behind anterior margin. Metanotum and abdominal tergites dark grey, connexiva brown on outer halves and ventrally. Legs with coxae, trochanters, and majority of femora, and all ventral surfaces yellowish brown; distal sections of femora, plus all tibiae and tarsi darker brown. Laterotergites below connexiva and all ventral surfaces dull black, except propleural region and genital segments brown.

Structural characters. Micropterous male: head of moderate length, declivant anteriorly, with weak impressed median line; length 0.40 , width 0.60 ; 
width of eye/interocular space, 0.15/0.30. Pronotum long, covering mesonotum, length/width, $0.35 / 1.00$. Metanotum length 0.30 . Abdominal tergites dull, without shining areas; lengths of tergites II-VII, respectively: $0.15: 0.10: 0.10: 0.10: 0.10$ $: 0.25$.

Entire dorsum and laterotergites covered with fine appressed golden pubescence, intermixed with scattered short, erect golden-brown setae; legs and antennae thickly clothed with short pale setae, scattered long erect black setae present along anterior margins of antennal segments I and II, anterior margins of all tibiae; fore femur ventral margin straight, not modified, bearing numerous short, erect pale setae along entire length, intermixed with evenly spaced comb of 6-8 long, erect, pilose pale brown setae; fore tibia with inner margin straight, distal grasping comb extending for $0.45 \times$ the length of the segment; middle tibia bearing a row of evenly spaced, long pilose pale setae of progressively decreasing length distally, longest and most basal of these setae with length approximately exceeding $2 \times$ width of tibia; hind femur with numerous short, erect pale setae along posterior margin, lacking tumescences or specialized setal tufts.

Pro- and mesosternum broadly sulcate along longitudinal midlines; metasternum slightly tumescent. Abdominal venter set with very short appressed pale setae, and scattered longer pale setae; abdominal ventrites I-IV unmodified; ventrites V and VI shallowly sulcate centrally along longitudinal midline; ventrite VI bearing a pair $(1+1)$ of transversely ovate tufts of short, dense dark setae to either side of depressed midline; ventrite VII with anterior half lying in nearly vertical orientation, slightly sulcate along longitudinal midline, weakly bitumescent to either side of this shallow medial depression, posterior half lying in horizontal orientation, forming a lamella adjacent to base of genital capsule. Proctiger produced anteriorly into a moderate length, blade-like process tapering to an acute apex (Fig. 18). Parameres vestigial or absent.

Antennal formula I : II : III : IV; $0.25: 0.24: 0.35$ : 0.47 .

Proportions of legs as follows: Femur, tibia, tarsal 1 , tarsal 2 of fore leg, $0.60: 0.50: 0.23: 0.0$; of middle leg, $0.70: 0.70: 0.15: 0.25$; of hind leg, $0.80: 0.95$ $: 0.15: 0.30$.

Micropterous female (Fig. 7). Similar to micropterous male in general structure and color, with following exceptions: all abdominal tergites with small patches of silvery setae laterally, tergites IV-VI with scattered silvery setae across their entire widths, abdominal tergite VIII flat, lying in an entirely horizontal orientation; connexiva broadly separated, bowing slightly outward, margins gradually convergent posteriorly, posterolateral apices of segment VII produced into small, angulate, posterior projections when viewed dorsally or laterally, apices of these angles bearing acuminate tufts of long, posteriorly-directed dark setae (Fig. 21); connexival margins of even width throughout, lacking specialized setal tufts other than those at posterior apices; abdominal venter unmodified, set with numerous very short pale setae; legs unmodified.

Macropterous female (Fig. 8). Similar to micropterous female in general structure and color, with following exceptions: pronotum greatly enlarged; anterior lobe bearing scattered long, erect dark setae laterally; posterior lobe with humeri prominent, forming rounded lateral knobs; central section of posterior lobe broadly domed, bearing short erect gold setae, and set of numerous obscure foveae; hind portion of posterior lobe roughly triangular, posterior apex blunt, bearing a few short silvery setae. Wings uniformly dull dark brown, lacking pale markings, not extending beyond tip of abdomen, bearing 4 closed cells, consisting of 2 moderately small cells in basal half of wing, and two more larger cells extending well into distal half of wing, veins delimiting basal cells set with numerous long, erect brown setae.

\section{Etymology}

The name "timikana" refers to the type locality, near the town of Timika in the southern part of western New Guinea.

\section{Distribution}

Western New Guinea (Fig. 9).

\section{Comparative notes}

Neusterensifer timikana is a dark-colored species that is superficially similar to $N$. sepik J. Polhemus \& D. Polhemus, with both these species possessing a pair $(1+1)$ of short, dense dark setal patches to either side of the longitudinal midline on male abdominal ventrite VI, but may be separated by the differently shaped process on the male proctiger which becomes constricted to a narrowed tip (Fig. 18), and the slightly upturned posterolateral angles of the female connexiva when viewed laterally (Fig. 21).

This is the species that was listed as "Neusterensifer sp. undet. \#1" by D. Polhemus \& J. Polhemus (2000c).

\section{Ecological notes}

The type locality was a broad, unshaded river in an alluvial bed of mixed cobble, sand and gravel, flowing across the foreland plain at the southern edge of the central New Guinea mountains. The channel contained alternating pools and shallow riffles, 


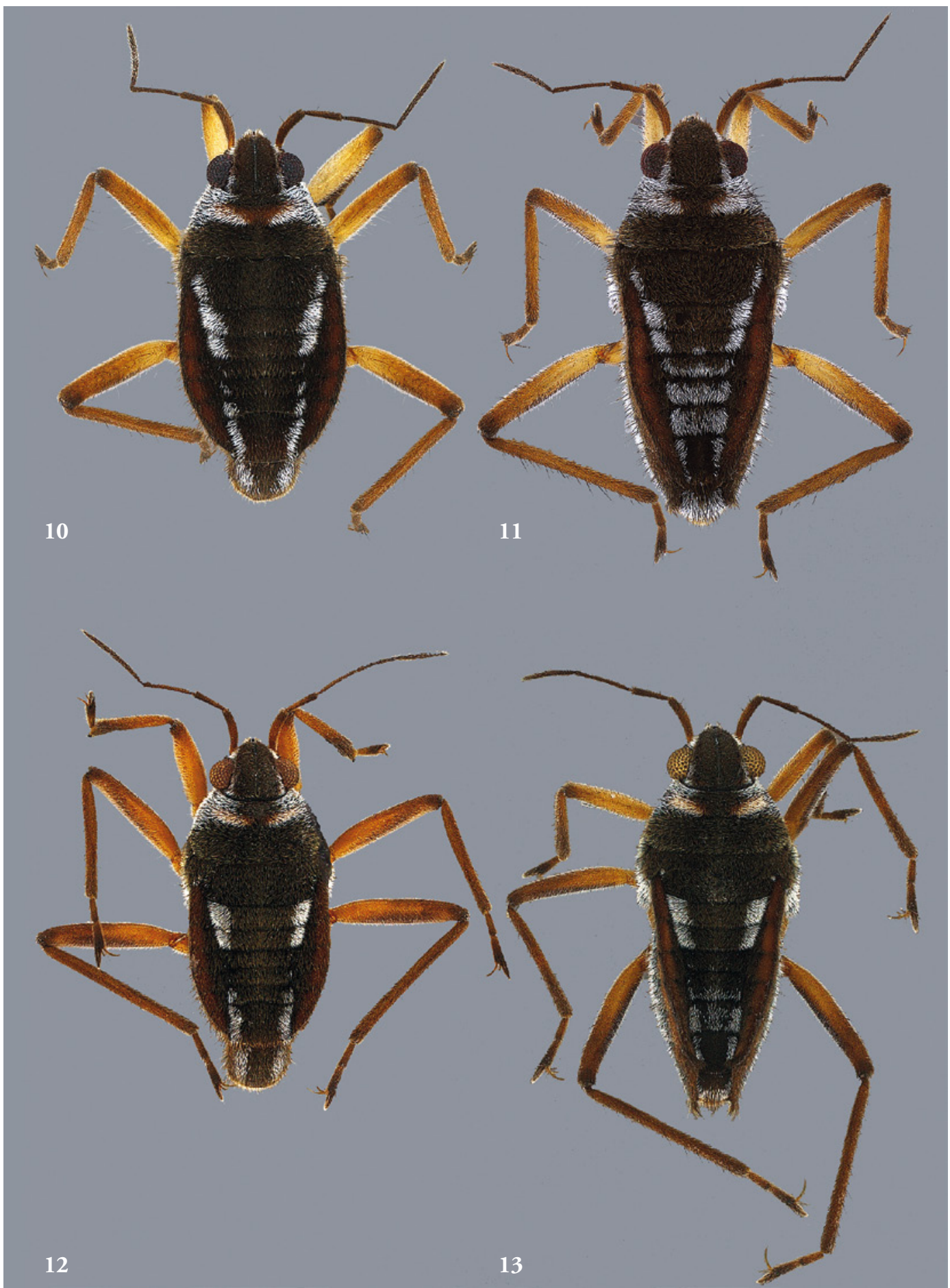

Figs 10-13. Neusterensifer species, dorsal habitus photos. 10. N. wondiwoi, micropterous male (specimen from New Guinea, Aisandami village, CL 7540); 11. N. wondiwoi, micropterous female (specimen from New Guinea, Aisandami village, CL 7540); 12. N. yobi, micropterous male (specimen from Yapen Island, Ambaidiru village); 13. N. yobi, micropterous female (specimen from Yapen Island, Ambaidiru village). 


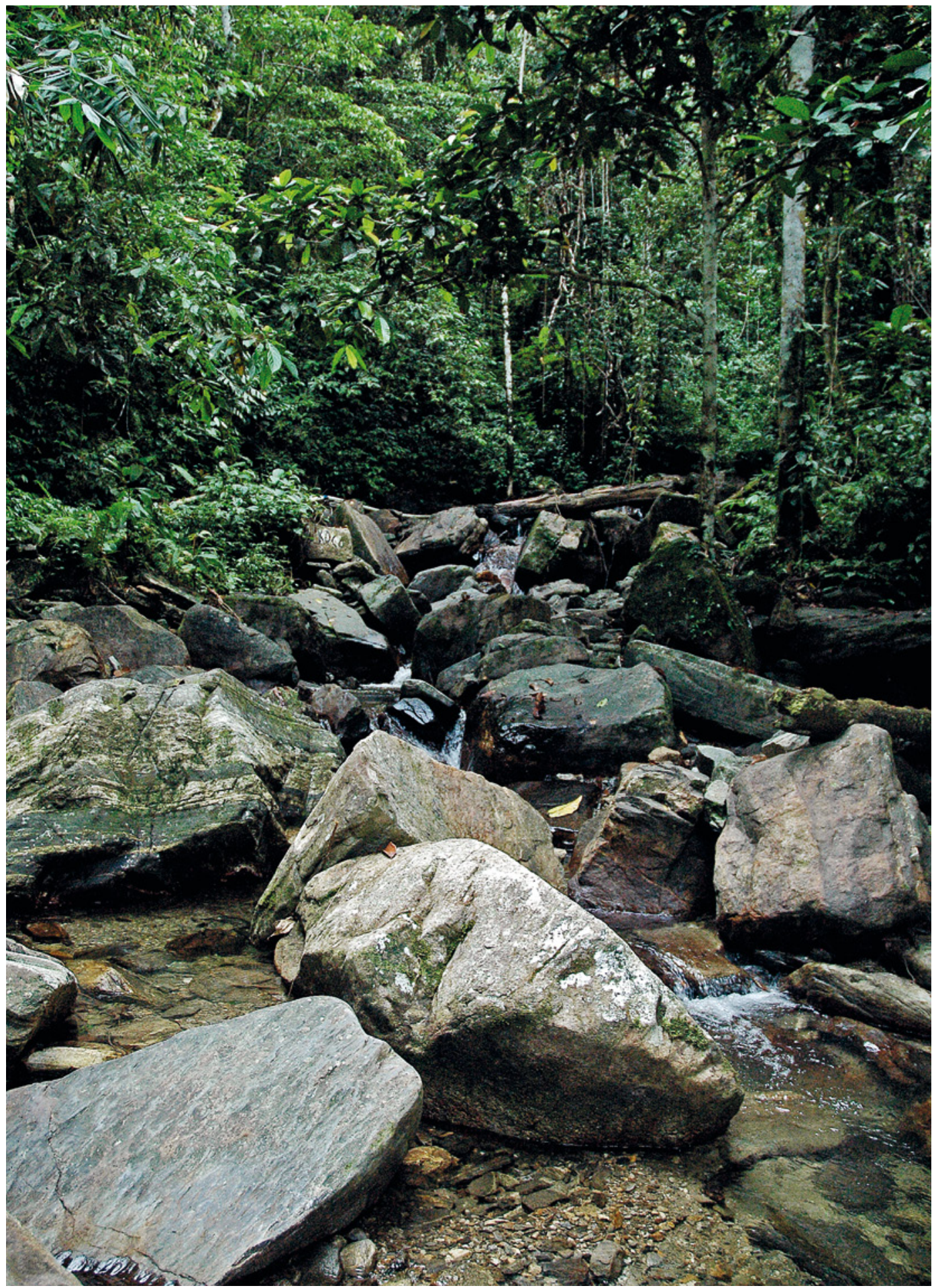

Fig. 14. Type locality of Neusterensifer wondiwoi, a rocky stream with metamorphic boulders on the west coast of the Wandammen Peninsula near Aisandami village. The type series was taken from shallow pools along the margins of the stream channel. 
bordered by primary rainforest. The type series of $N$. timikana was taken from small pools formed amid cobbles along the channel margins.

Based on known collections, this species occupies the Arafura Foreland area of freshwater endemism (Area 23) as defined by Polhemus \& Allen (2007).

\section{Neusterensifer wondiwoi sp. $\mathbf{n}$.}

Figs 5, 10, 11, 14, 15, 22

Type material. Holotype, micropterous male: Indonesia, West Papua Prov. [= former Irian Jaya Prov.], Wandammen Peninsula, west coast, swift stream entering south side of Manu [Dwairi] Bay near Aisandami village, 0-60 m. [0-200 ft.],2²9'30"S, $134^{\circ} 32^{\prime} 27^{\prime \prime}$ E, water temp. $26^{\circ} \mathrm{C}$., 11 November 2008, 15:30-17:00 hrs., CL 7540, D. A. Polhemus (USNM).

Paratypes: Indonesia, West Papua Prov. [= former Irian Jaya Prov.]: 2 macropterous males, 2 macropterous females, 11 micropterous males, 6 micropterous females, same data as holotype, D. A. Polhemus (USNM, BPBM)

\section{Description}

Size. Micropterous male, length $2.30-2.65 \mathrm{~mm}(\overline{\mathrm{x}}=$ $2.49, \mathrm{n}=7)$; width $1.05-1.22 \mathrm{~mm}(\overline{\mathrm{x}}=1.13, \mathrm{n}=$ 7). Micropterous female, length $2.60-2.95 \mathrm{~mm}(\overline{\mathrm{x}}=$ $2.83, \mathrm{n}=5)$; width $1.10-1.15 \mathrm{~mm},(\overline{\mathrm{x}}=1.12, \mathrm{n}=5)$. Macropterous male, length $2.60 \mathrm{~mm}(\mathrm{n}=1)$; width $1.20 \mathrm{~mm},(\mathrm{n}=1)$. Macropterous female, length 2.75 $\mathrm{mm}(\mathrm{n}=1)$; width $1.20 \mathrm{~mm},(\mathrm{n}=1)$.

Color. Micropterous male (Fig. 10): Ground color dark grey, marked with orange brown on anterior pronotum, brown on outer portions of connexiva; patches of short, shining, silvery pubescence present laterally on frons, vertex, pronotum, metanotum, and abdominal tergites II, III, V-VIII, in broad band across anterior pronotum; and scattered on sides of thorax and abdomen. Head dark grey; eyes dark red; antennae uniformly medium brown; rostrum dark yellow, dark brown medially, piceous distally. Pronotum dark grey, bearing an elongate transverse orange brown patch behind anterior margin, width of this patch subequal to width of vertex. Metanotum and abdominal tergites dark grey, connexiva brown on outer halves and ventrally. Legs yellowish brown with distal apices of femora and tibiae plus all tarsi darker brown. Laterotergites below connexiva and all ventral surfaces dull grayish-black, except propleural region and genital segments brown.

Structural characters. Micropterous male: head of moderate length, declivant anteriorly, with weak impressed median line; length 0.30 , width 0.62 ; width of eye/interocular space, $0.15 / 0.32$.
Pronotum long, covering mesonotum, length/width, $0.40 / 1.10$. Metanotum length 0.30 . Abdominal tergites dull, without shining areas; lengths of tergites II-VII, respectively: $0.20: 0.12: 0.12: 0.10: 0.10$ $: 0.30$.

Entire dorsum and laterotergites covered with fine appressed golden pubescence, intermixed with numerous, moderately long, erect brown setae; legs and antennae thickly clothed with short pale setae, scattered long erect brown setae present along anterior margins of antennal segments I and II, anterior margins of all tibiae; fore femur with ventral margin straight, not modified, bearing numerous short, erect pale setae along entire length, intermixed with evenly spaced comb of 6-8 long, erect, pilose pale setae; fore tibiae with inner margin straight, distal grasping comb extending for $0.5 \times$ the length of the segment; middle tibia bearing a row of evenly spaced, long pilose pale setae of progressively decreasing length, longest and most basal of these setae with length approximately exceeding $2 \times$ width of tibia; hind femur with numerous short, erect pale setae along posterior margin, lacking tumescences or specialized setal tufts.

Pro- and mesosternum broadly sulcate along longitudinal midlines; metasternum slightly tumescent. Abdominal venter set with very short appressed pale setae, and scattered longer pale setae; abdominal ventrites I-IV unmodified; ventrites V and VI raised centrally along longitudinal midline to form a low tumescence in the form of a triangle with a posteriorly directed apex, lateral margins of this low tumescence set with numerous moderately long, golden setae, forming a continuous golden setal patch in the form of a V-shape with the apex directed posteriorly; ventrite VII broadly depressed centrally. Proctiger produced anteriorly into a long, slender, sinuate process with a slightly hooked apex (Fig. 15). Parameres vestigial or absent.

Antennal formula I : II : III : IV; $0.30: 0.25: 0.40$ : 0.50 .

Proportions of legs as follows: Femur, tibia, tarsal 1, tarsal 2 of fore leg, $0.62: 0.60: 0.30: 0.0$; of middle leg, $0.80: 0.80: 0.12: 0.28$; of hind leg, $1.00: 1.10$ : $0.20: 0.29$.

Micropterous female (Fig. 11). Similar to micropterous male in general structure and color, with following exceptions: abdominal tergites IV-VI bearing narrow bands of silvery setae across their posterior margins, abdominal tergite VII compressed between connexiva into a narrow, acute, triangle with apex directed posteriorly, abdominal tergite VIII hidden under convergent posterior angles of connexiva; connexiva broadly separated anteriorly, bowing outward, strongly convergent posteriorly, meeting over 
abdominal tergite VIII and hiding it from dorsal view, posterolateral apices of segment VII produced into acutely angulate posterior projections when viewed both dorsally and laterally, these projections flanked subapically by small tufts of moderately long, erect brown setae (Fig. 22); connexival margins of even width throughout; lateroventrites on segment VII produced anteriorly in a broad crescent shape, this area depressed to form a broad, shallow, vertically aligned sulcus; abdominal venter unmodified, set with numerous very short pale setae; legs unmodified.

Macropterous male. Similar to micropterous male in general structure and color, with following exceptions: pronotum greatly enlarged; posterior lobe with humeri prominent, forming rounded lateral knobs; central section of posterior lobe broadly domed, bearing short erect gold setae, and set with numerous obscure foveae; hind portion of posterior lobe roughly triangular, posterior apex broadly rounded, bearing a few long, brown setae. Wings extending beyond tip of abdomen, bearing 4 closed cells, consisting of 2 moderately small cells in basal half of wing, and two larger cells extending well into distal half of wing; veins delimiting basal cells set with numerous long, erect brown setae; overall coloration of wings dull dark brown, with narrow pale tan streaks in the two basal cells, and faint indications of pale tan centrally in the two distal cells.

Macropterous female. Similar to micropterous female in general structure and color, with following exceptions: wings not exceeding tip of abdomen, with apices of posterior connexival projections slightly visible beyond wingtips when viewed dorsally.

\section{Etymology}

The name "wondiwoi" is a noun in apposition and refers to the Wondiwoi Mountains of the Wandammen Peninsula, the type locality for this species.

\section{Distribution}

Western New Guinea (Fig. 5).

\section{Comparative notes}

Neusterensifer wondiwo i is a dark brown species with rather extensive silvery markings on the dorsal female abdomen (Figs 10,11), and can be easily recognized by the very slender, gently curving process on the male proctiger (Fig. 15), the relatively unmodified male abdominal ventrites which lack tubercles or prominently raised patches of setae, and the sharply pointed form of the terminal female abdominal segment when viewed laterally (Fig. 22). In addition, the laterotergites on female abdominal segment VII are depressed so as to form a broad, shallow, verti- cally oriented, crescent-shaped sulcus, which may allow infolding of the female hind femur against the abdomen.

\section{Ecological notes}

The type locality was a swift, clear stream that served as a village water supply, occupying a boulder-strewn channel in a narrow, shady gorge cut into metamorphic rocks (Fig. 14), with waterfalls at the upper end. The type series of $N$. wondiwo $i$ was taken from small pockets of water amid rocks and cobbles along the margins of this stream in the gorge area below the falls.

Based on known collections, this species occupies the Vogelkop Anticlines area of freshwater endemism (Area 6) as defined by Polhemus \& Allen (2007).

\section{Neusterensifer yobi sp. $\mathbf{n}$.}

Figs 9, 12, 13, 19, 20

Type material. Holotype, micropterous male: Indonesia, Papua Prov. [= former Irian Jaya Prov.], Yapen Is., Ambaidiru village, brook (Kali Manatiuna) running through village and degraded forest, $1^{\circ} 45^{\prime} 47^{\prime \prime} S, 136^{\circ} 10^{\prime} 44^{\prime \prime E,} 16$ July 2006, VJK2006NG093, V. Kalkman (BPBM).

Paratypes: Indonesia, Papua Prov. [= former Irian Jaya Prov.]: 10 micropterous males, 8 micropterous females, same data as holotype, V. Kalkman (USNM, BPBM); 4 micropterous males, 2 micropterous females, Yapen Is., north coast, Yobi, river partly in degraded forest and partly in virgin forest, $1^{\circ} 32^{\prime} 20^{\prime \prime}$, $136^{\circ} 28^{\prime} 40$ ”E, 18 July 2006, VJK2006NG268, V. Kalkman (BPBM).

\section{Description}

Size. Micropterous male, length $2.32-2.45 \mathrm{~mm}(\overline{\mathrm{x}}=$ $2.37, \mathrm{n}=7)$; width $0.95-1.05 \mathrm{~mm}(\overline{\mathrm{x}}=1.00, \mathrm{n}=$ 7). Micropterous female, length $2.50-2.70 \mathrm{~mm}(\overline{\mathrm{x}}=$ $2.60, \mathrm{n}=7)$; width $1.00-1.10 \mathrm{~mm},(\overline{\mathrm{x}}=1.05, \mathrm{n}=7)$. Color. Micropterous male (Fig. 12): Ground color dark grey, marked with orange-brown on anterior pronotum and outer halves of connexiva; patches of short, shining, silvery pubescence present laterally on frons, vertex, pronotum, metanotum, and abdominal tergites II, III, VI-VIII, in broad band across anterior pronotum; and on sides of thorax and abdomen. Head dark grey; eyes dark red; antennae with basal two-thirds of segments I and II yellowishbrown, remaining distal portions of segments I and II and all of segments III and IV medium brown; rostrum dark yellow, dark brown medially, piceous distally. Pronotum dark grey, bearing an elongate transverse orange brown patch behind anterior margin, width of this patch subequal to width of vertex. 


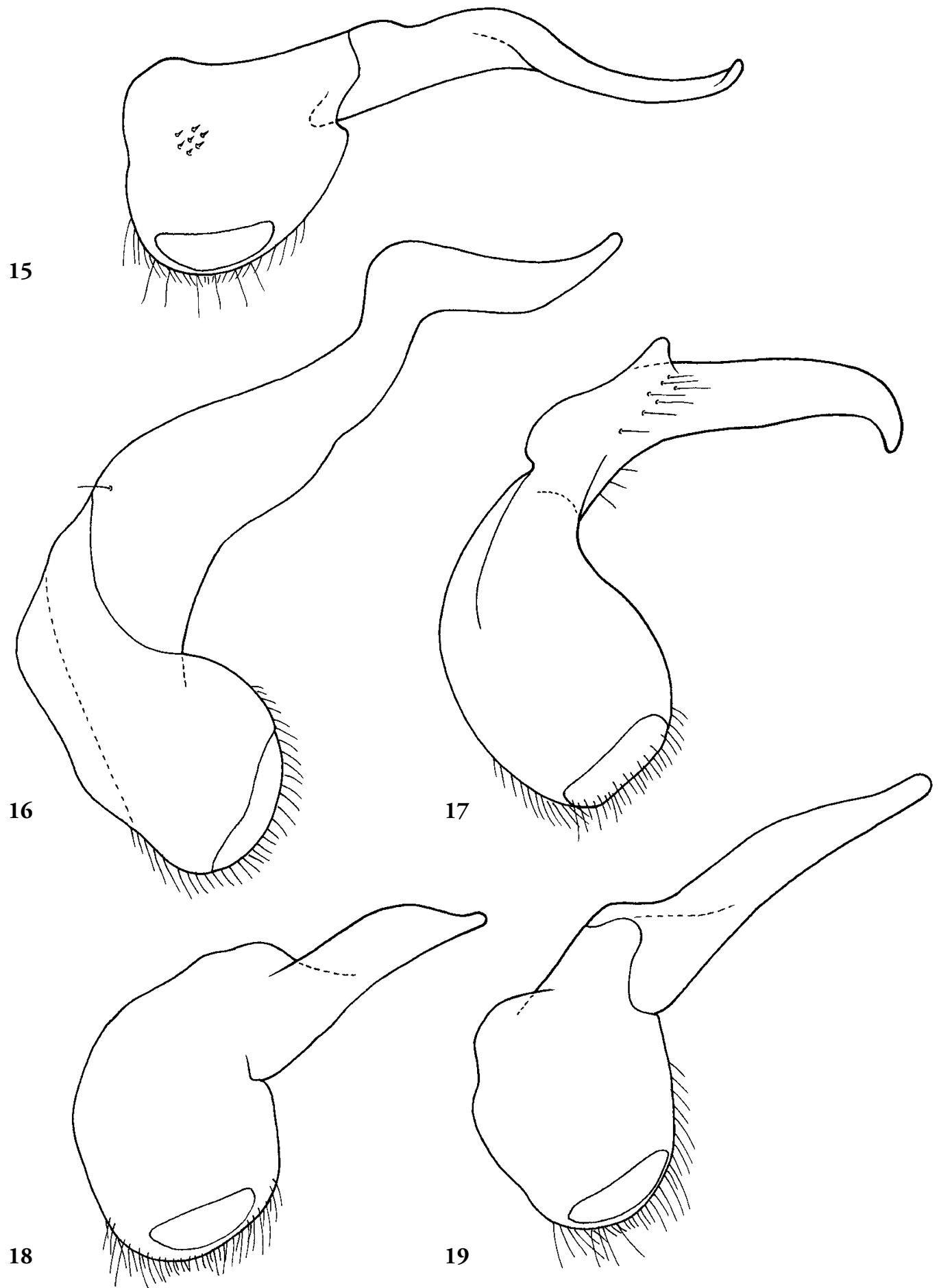

Figs 15-19. Neusterensifer species, male proctiger shapes, ventral views. 15. N. wondiwoi; 16. N. dabrana; 17. N. terrestris; 18. N. timikana; 19. N. yobi 


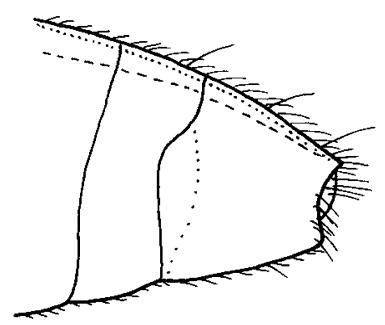

20

21

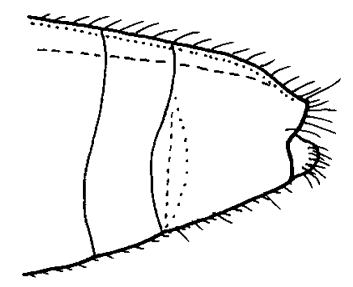

22

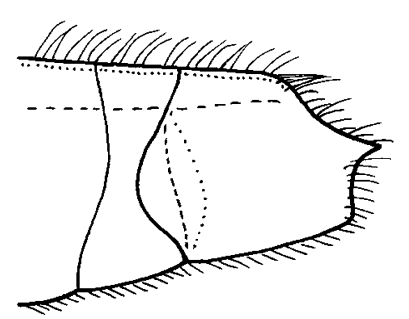

23

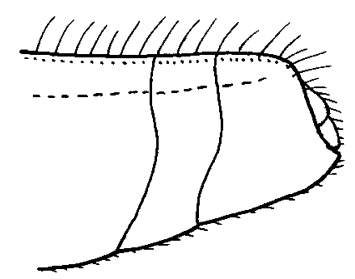

24

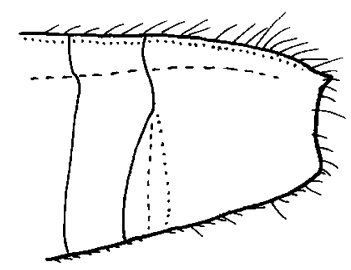

Figs 20-24. Neusterensifer species, female terminal abdomen, lateral views. 20. N. yobi; 21. N. timikana; 22. N. wondiwoi; 23. N. terrestris; 24 . N. dabrana
Metanotum and abdominal tergites dark grey, connexiva orange-brown on outer halves and ventrally. Legs yellowish-brown; distal apices of femora and distal tarsi darker brown. Laterotergites below connexiva and all ventral surfaces dull black, except propleural region, mesoacetabulae and abdominal ventrites VII-IX yellowish brown.

Structural characters. Micropterous male: head of moderate length, declivant anteriorly, with weak impressed median line; length 0.30 , width 0.60 ; width of eye/interocular space, $0.15 / 0.30$. Pronotum long, covering mesonotum, length/width, $0.40 / 1.00$. Metanotum length 0.40 . Abdominal tergites dull, without shining areas; lengths of tergites II-VII, respectively: $0.20: 0.15: 0.10: 0.10: 0.10$ $: 0.30$.

Entire dorsum and laterotergites covered with fine appressed golden pubescence, intermixed with scattered medium length, erect golden-brown setae; legs and antennae thickly clothed with short pale setae, scattered long erect golden-brown setae present along anterior margins of antennal segments I and II, anterior margins of all tibiae; fore femur ventral margin straight, not modified, bearing numerous short, erect pale setae along entire length, intermixed with evenly spaced comb of 6-8 long, erect, pilose pale setae; fore tibiae with inner margin straight, distal grasping comb extending for $0.45 \times$ the length of the segment; middle tibia bearing a row of evenly spaced, long pilose pale setae of progressively decreasing length, longest and most basal of these setae with length approximately exceeding $2 \times$ width of tibia; hind femur with numerous short, erect pale setae along posterior margin, lacking tumescences or specialized setal tufts.

Pro- and mesosternum broadly sulcate along longitudinal midlines; metasternum slightly tumescent. Abdominal venter set with very short appressed pale setae, and scattered longer pale setae; abdominal ventrites I-IV unmodified; ventrites V and VI shallowly sulcate centrally along longitudinal midline; central portion of ventrite VI produced posteriorly into a roughly trapezoidal projection extending posteriorly over base of ventrite VII, lateral margins of the projection converging posteriorly, densely set with short, stiff, shining golden setae, middle portion of projection bearing a pair $(1+1)$ of patches of short, dense, dark setae to either side of slightly depressed longidudinal midline, posterior apex of projection truncate, bearing a few long, pale, posteriorly directed setae; ventrite VII bitumescent basally, bearing a pair $(1+1)$ of rounded tumescences in the section beneath the overhanging central section of ventrite VI, these tumescences narrowly separated by incised longitudinal midline, posterior and lateral sections of 
ventrite VII adjacent to these tumescences depressed and flattened. Proctiger produced anteriorly into a moderately long, slightly sinuate, blade-like process tapering to a bluntly rounded apex (Fig. 19). Parameres vestigial or absent.

Antennal formula I : II : III : IV; $0.35: 0.30: 0.40$ : 0.50 .

Proportions of legs as follows: Femur, tibia, tarsal 1, tarsal 2 of fore leg, $0.60: 0.50: 0.20: 0.0$; of middle leg, $0.70: 0.80: 0.18: 0.30$; of hind leg, $0.90: 1.20$ : $0.20: 0.30$.

Micropterous female (Fig. 13). Similar to micropterous male in general structure and color, with following exceptions: general coloration dark brown; pale markings on anterior pronotum consisting of a pair $(1+1)$ of transverse, roughly rectangular dark yellow patches broadly separated by a dark coloration along the longitudinal midline; outer halves of connexiva dark orange; all antennal and leg segments medium brown with distal apices of tibiae and tarsi darker brown; patches of silvery setae present laterally on abdominal tergites II, III, and V-VII, these silvery setae also forming narrow transverse bands across posterior margins of tergites $\mathrm{V}$ and VI; abdominal tergite VIII with anterior three quarters lying $45^{\circ}$ from vertical when viewed laterally, posterior one quarter bent more sharply downward into nearly vertical orientation; proctiger barely visible below tergite VIII, lying in nearly vertical orientation; connexival margins nearly straight, evenly convergent posteriorly, widely separated, leaving all tergites visible from above, inner faces of segments VII bearing small, inwardly directed tubercles projecting over posterolateral portions of tergite VII, apices of these tubercles bearing small, acute tufts of pale setae; posterolateral angles of segment VII produced into small, angulate, posterior projections when viewed both dorsally and laterally (Fig. 20); connexival margins of even width throughout, lacking specialized setal tufts; lateroventrites on segment VII slightly produced anteriorly in a crescentic shape, this area of the segment depressed to form a broad, shallow, vertically dimpled sulcus; abdominal venter unmodified, set with numerous very short pale setae; legs unmodified.

Macropterous form. Unknown.

\section{Etymology}

The name "yobi" is a noun in apposition and refers to the village of Yobi on Yapen Island, near which the type series of this species was collected.

\section{Distribution}

Yapen Island (Fig. 9).

\section{Comparative notes}

Neusterensifer yobi is a dark brown species (Figs 12, 13) that can be recognized by the form of the process on the male proctiger which is relatively short and has a broadly rounded apex (Fig. 19), the structure of the male ventral abdomen in which ventrite VI possesses a trapezoidal process projecting posteriorly over the bitumescent base of ventrite VII, and by the concave form of the posterior margin of the female abdomen when viewed laterally (Fig. 20). The female abdomen is also distinctive when viewed from above in that it bears small, inwardly-directed tubercles on the inner faces of the seventh connexival segment, which project over the posterolateral portions of tergite VII. In addition, the female seventh laterotergites are slightly depressed to form small, vertical sulci, in a manner reminiscent to, but less pronounced than, the character state seen in $N$. wondiwoi.

\section{Biological notes}

No information is available on the habits of this species except the label data indicating that the type series was taken from a "river partly in degraded forest and partly in virgin forest." Based on known collections, this species occupies the Yapen Island area of freshwater endemism (Area 9) as defined by Polhemus \& Allen (2007).

\section{Neusterensifer gladius Polhemus \& Polhemus} Fig. 5

Neusterinsifer gladius J. Polhemus \& D. Polhemus 1994: 70.

Material examined. Indonesia, West Papua Prov. [= former Irian Jaya Prov.]: 4 macropterous males, 4 macropterous females, 11 micropterous males, 8 micropterous females, Mangguar Peninsula, stream on east coast, N. of Jauer village, 0-45 m [0-150 ft], 300'04”S, 13449'19”E, water temp. $25^{\circ} \mathrm{C}$., 10 November 2008, 08:30-10:45 hrs., CL 7537, D. A. Polhemus (BPBM); 7 micropterous males, 8 micropterous females, Wandammen Peninsula, rocky river and tribs. on east coast near northern tip, 0-120 m. [0-400 ft.], water temp. $25^{\circ} \mathrm{C}$., 9 November 2008, 08:00-14:00 hrs., CL 7535, D. A. Polhemus (BPBM); 1 macropterous male, 1 macropterous female, 19 micropterous males, 23 micropterous females, Wandammen Peninsula, west coast, swift stream entering south side of Manu [Dwairi] Bay near Aisandami village, 0-60 m. [0-200 ft.], $2^{\circ} 29^{\prime} 30^{\prime \prime} \mathrm{S}, 134^{\circ} 32^{\prime} 27^{\prime \prime} \mathrm{E}$, water temp. $26^{\circ} \mathrm{C}$., 11 November 2008, 15:30-17:00 hrs., CL 7540, D. A. Polhemus (USNM).

\section{Comparative notes}

This species was previously described from a short series taken at a waterfall inland from Nabire, in company with a far larger series of $N$. nabire 
J. Polhemus \& D. Polhemus. These new records extend the geographic range of this species well to the west, onto the Mangguar and Wandammen peninsulas.

\section{Biogeographic discussion}

The new discoveries and range extensions reported in this paper are useful in refining the scheme of freshwater areas of endemism proposed by D. Polhemus \& Allen (2007), and highlight the position of the Nabire area at the southeastern margin of Cenderawasih Bay as a potential contact zone between two such areas. For instance, the Mangguar and Wandammen peninsulas represent separate geological terranes in the scheme of Pigram \& Davies (1987), but the distribution of Neusterensifer gladius on both terranes (Fig. 5), and nowhere else, indicates they have shared similar biotic histories. In addition, the absence of $N$. nabire in these two areas suggests that the core range of this latter species probably lies further to the east, in the Weyland Mountains, and that the Nabire area represents a contact zone between the respective ranges of taxa endemic to the Weyland Mountains on one side ( $N$. nabire) and the Mangguar/Wandammen terranes ( $N$. gladius) on the other.

In addition, based on this new veliid data, as well as recent Argiolestes damselfly descriptions (Kalkman et al. 2010), it appears that Area 6 (Vogelkop Anticlines) as proposed by D. Polhemus \& Allen (2007) may warrant subdivision to accommodate the Wandammen Peninsula and adjacent Roon Island as a separate area of freshwater endemism. Although current distributions of both Neusterensifer and Argiolestes are not inconsistent with retaining Area 6 as currently defined, the unit's combination of geographic features of disparate geological origin, including the Lengguru Fold Belt anticlines, the Etna Bay area, Lake Yamur, and the Wandammen and Mangguar peninsulas was largely a compromise solution based on inadequate survey data. As noted by D. Polhemus \& Allen (2007): “The Wandammen Peninsula has also been included in this unit, but this mountainous sliver of Australian craton will likely prove to be yet another discrete area of aquatic endemism once adequate faunal surveys are conducted." With the advent of such surveys and consequently refined distributional knowledge, this hypothesis has gained support.

\section{Acknowledgments}

We wish to thank Debbie Gowensmith of Conservation International for organizing the survey of the central Mamberamo River basin in 2000 under the auspices of that organization's Rapid Assessment Program, which led to the discovery of several of the new species described herein. Similar thanks go to Mark Erdmann and Gerry Allen, also of Conservation International, for inviting the first author on a combined marine and freshwater survey of the Cenderawasih Bay region in 2008 that produced informative collections from the Wandammen and Mangguar peninsulas containing another new species. Special thanks are also due to Howard Lewis and Kent Hortle of the PTFI environmental laboratory, for facilitating surveys of the Ajkwa River basin in the vicinity of Timika in 1997 and allowing use of their excellent facilities. Finally, a further note of gratitude is due to Vincent J. Kalkman of the Netherlands Centre for Biodiversity Naturalis, Leiden, who kindly provided specimens that he collected on the island of Yapen in 2006.

The first author also gratefully acknowledges Allen Allison and Neal Evenhuis of the Bishop Museum, Honolulu, Hawaii (BPBM), for their continuing logistical support and intellectual comradery. The second author conducted this research as an adjunct faculty member in the Dept. of Entomology at Colorado State University, Fort Collins, Colorado. We jointly thank both organizations for their continued support of our research into the systematics and zoogeography of aquatic Heteroptera.

The holotypes of the new species described herein are deposited in the National Museum of Natural History, Smithsonian Institution, Washington, DC (USNM); paratypes are held in that collection, and in the Bishop Museum. This paper represents a contribution to the latter institution's Pacific Biological Survey.

\section{References}

Chen, P-p., N. Nieser \& I. Lansbury, 2008. Notes on aquatic and semiaquatic bugs (Hemiptera: Heteroptera: Nepomorpha, Gerromorpha) from Malesia with description of three new species. - Acta Entomologica Musei Nationalis Pragae 48 (2): 269-279.

Kalkman, V.J., S.J. Richards, \& D.A. Polhemus, 2010. Three new species of Argiolestes, with a key to the males of Argiolestes sensu stricto (Odonata: Megapodagrionidae). - Journal of Odonatology, 13 (1): 7588.

Pigram, C.J. \& H.L. Davies, 1987. Terranes and the accretion history of the New Guinea orogen. - Journal of Australian Geology and Geophysics, 10: 193-211.

Perkins, P.D., 2011. New species (130) of the hyperdiverse aquatic beetle genus Hydraena Kugelann from Papua New Guinea, and a preliminary analysis of areas of endemism (Coleoptera: Hydraenidae). - Zootaxa, 2944: $1-417$. 
Polhemus, D.A., 2011. New distributional records for Gyrinidae (Insecta: Coleoptera) on New Guinea and nearby islands, with a checklist of the New Guinea species. - Zootaxa, 2900: 51-68.

Polhemus, D.A. \& G.A. Allen, 2007. Freshwater biogeography of Papua. - In: A.J. Marshall \& B.M. Beehler (eds), Ecology of Papua, 1. Periplus Editions (HK) Ltd., Singapore: 207-245.

Polhemus, D.A. \& J.T. Polhemus, 2000a. Additional new genera and species of Microveliinae (Heteroptera: Veliidae) from New Guinea. - Tijdschrift voor Entomologie, 143: 91-123.

Polhemus, D.A. \& J.T. Polhemus, 2000b. New species of Microveliinae (Heteroptera: Veliidae) from the Raja Ampat Islands. - Tijdschrift voor Entomologie, 143: 279-289.

Polhemus, D.A. \& J.T. Polhemus, 2000c. A biodiversity survey of aquatic insects in Ajkwa River Basin and adjacent areas, Irian Jaya, Indonesia. - Tropical Biodiversity, 5 (3): 197-216.
Polhemus, D.A. \& J.T. Polhemus, 2001. A revision of the genus Ptilomera (Heteroptera: Gerridae) on New Guinea and nearby islands. - Journal of the New York Entomological Society, 109 (1): 81-166.

Polhemus, D.A. \& J.T. Polhemus, 2004. Two new genera and thirty new species of Microveliinae (Heteroptera: Veliidae) from the East Papua Composite Terrane, far eastern New Guinea. - Tijdschrift voor Entomologie, 147: 113-189.

Polhemus, J.T. \& D.A. Polhemus, 1994. Four new genera of Microveliinae from New Guinea. - Tijdschrift voor Entomologie, 137: 57-74.

Received: 29 August 2011

Accepted:7 October 2011 


\section{Appendix}

\section{Checklist of the Neusterensifer species and their geographic ranges.}

Species are assigned to areas of freshwater endemism as defined in Polhemus \& Allen (2007); the names of these areas are provided in the note below the checklist. For each species in the checklist, specific river basins or other localities of known occurrence are referenced, parenthetically followed by the broader area of freshwater endemism in which these localities lie.

Genus Neusterensifer

acuminata D. \& J. Polhemus 2000: 119

Adelbert Mtns. (Area 14)

aviavi D. \& J. Polhemus 2004: 185

Lakekamu River Basin (Area 25)

batantana D. \& J. Polhemus 2000: 282

Batanta Is. (Area 2)

bowutu D. \& J. Polhemus 2004: 179

Bowutu Mtns. (Area 22)

compactus J. \& D. Polhemus 1994: 69

East Papuan Central Highlands (Area 21)

cyclops J. \& D. Polhemus 1994: 69

Cyclops Mtns. (Area 12)

dabrana D. \& J. Polhemus 2011: 143

Mamberamo Foreland (Area 17)

dentrecasteaux D. \& J. Polhemus 2004: 172

Papuan Peninsula, D’Entrecasteaux Is. (Areas

30, 34, 35)

etna D. \& J. Polhemus 2000: 121

Etna Bay (Area 6)

femoralis D. \& J. Polhemus 2004: 157

Papuan Peninsula, D'Entrecasteaux Is. (Areas

30, 34, 35)

gamensis D. \& J. Polhemus 2000: 283

Gam Is. (Area 1)

gladius J. \& D. Polhemus 1994: 70

Mangguar and Wandamman Peninsulas

(Area 6)

goilala D. \& J. Polhemus 2004: 181

Owen Stanley Mountains (Area 31)

hunteri D. \& J. Polhemus 2004: 160

Papuan Peninsula, D’Entrecasteaux Is.

(Areas 30, 34, 35)

iriana D. \& J. Polhemus 2000: 122

Star Mtns. (Area 20)

kula D. \& J. Polhemus 2004: 174

D'Entrecasteaux Is. (Area 35)

kutubu D. \& J. Polhemus 2000: 115

Kikori River Basin (Area 25)

louisiadae D. \& J. Polhemus 2004: 163

Rossel Is. (Area 39), Tagula Is. (Area 38)

lubu D. \& J. Polhemus 2000: 115

Kikori and Lakekamu River Basins (Area 25) microrivula D. \& J. Polhemus 2004: 184

Lakekamu River Basin (Area 25)

misima D. \& J. Polhemus 2004: 168

Misima Is. (Area 37)

misoolicus D. \& J. Polhemus 2000: 281

Misool Is. (Area 3)

muyuw D. \& J. Polhemus 2004: 170

Woodlark Is. (Area 40)

nabire J. \& D. Polhemus 1994: 71

Weyland Mountains (Area 19)

pseudocyclops D. \& J. Polhemus 2000: 117

Trans-Fly Foreland (Area 24)

sagarai D. \& J. Polhemus 2004: 155

Cloudy Mountains (Area 34)

sepik J. \& D. Polhemus 1994: 72

Sepik River Basin (Area 16)

stysi Chen, Nieser \& Lansbury 2008: 275

Prince Alexander Mountains (Area 13)

sulcata D. \& J. Polhemus 2004: 165

Tagula Is. (Area 38)

terrestris D. \& J. Polhemus 2011: 142

Mamberamo Foreland (Area 17)

timikana D. \& J. Polhemus 2011: 146

Ajkwa River Basin (Area 23)

tufi D. \& J. Polhemus 2004: 177

Cape Nelson Peninsula (Area 33)

wondiwoi D. \& J. Polhemus 2011: 150

Wandammen Peninsula (Area 6)

yela D. \& J. Polhemus 2004: 164

Rossel Is. (Area 39)

yobi D. \& J. Polhemus 2011: 151

Yapen Is. (Area 9)

Note. Areas of freshwater endemism in the New Guinea region as defined in Polhemus \& Allen (2007) and referenced in the checklist above: Area 1. Waigeo Is.; Area 2. Batanta Is.; Area 3. Misool Is.; Area 4. Vogelkop Lowlands; Area 5. Vogelkop Highlands; Area 6. Vogelkop Anticlines; Area 7. Fakfak and Kumafa Mountains; Area 8. Biak and Supiori Islands; Area 9. Yapen Is.; Area 10. Northwest Papuan Coastal Lowlands; Area 11. Van Rees and Foja Mountains; Area 12. Cyclops Mountains; Area 13. Bewani, Torricelli and Prince Alexander Mountains; Area 14. Adelbert, Finisterre and Saruwaged Mountains; Area 15. Mamberamo Basin; Area 16. Sepik-Ramu-Markham Basin; Area 17. Mamberamo Foreland; Area 18. Sepik-Ramu Foreland; Area 19. Weyland Mountains; Area 20. West Papuan Central Highlands; Area 21. East Papuan Central Highlands; Area 22. Morobe Highlands; Area 23. Arafura Foreland; Area 24. Trans-Fly Foreland; Area 25. Papuan Gulf Foreland; Area 26. Arafura Coastal Lowlands; Area 27. Trans-Fly Coastal Lowlands; Area 28. Papuan Gulf Coastal Lowlands; Area 29. Aru Islands; Area 30. South Papuan Peninsula Foreland; Area 31. Owen Stanley Mountains; Area 32. Popondetta Foreland; Area 33. Cape Nelson Peninsula; Area 34. Cloudy Mountains; Area 35. D'Entrecasteaux Islands; Area 36. Basilaki Island; Area 37. Misima Is.; Area 38. Tagula Is.; Area 39. Rossel Is.; Area 40. Woodlark Is. 